\title{
Indications of low macrobenthic activity in the deep sediments of the eastern Mediterranean Sea*
}

\author{
DANIELA BASSO ${ }^{1}$, JOHN THOMSON² and CESARE CORSELLI ${ }^{1}$. \\ ${ }^{1}$ Dipartimento di Scienze Geologiche e Geotecnologie, Università degli Studi di Milano-Bicocca, Piazza della Scienza 4, \\ 20126 Milano, Italy. E-mail: daniela.basso@unimib.it \\ ${ }^{2}$ Southampton Oceanography Centre, Empress Dock, Southampton SO14 3ZH, U.K.
}

\begin{abstract}
SUMMARY:The fluxes and budget of organic matter from the oligotrophic surface waters of the eastern Mediterranean to the deep waters are poorly known, and little information is available on past and present macrobenthic activity on the sea floor. Evidence of macrobenthic activity can be direct, through recovery of living organisms or their autochthonous skeletal remains, or indirect, through bioturbation and trace fossils. The evidence of biological activity in deep eastern Mediterranean sediments has been evaluated and compared through ${ }^{210} \mathrm{~Pb}$ profiles from box-cores and study of dredge samples from sites on Medina Rise (1374 m water depth), the Messina Abyssal Plain (4135 m) and several sites along the Mediterranean Ridge, SW and S of Crete $(1783$ to $3655 \mathrm{~m})$. All these sites are remote from the continental shelves, so the biological benthic activity is expected to depend primarily on primary production from surface waters. The results show that present-day macrobenthos and trace fossils are generally scarce, especially at depths $>2500 \mathrm{~m}$. This observation is supported by surface sediment ${ }^{210} \mathrm{~Pb}_{\text {excess }}$ distributions that show a surface mixed layer (SML) $<6 \mathrm{~cm}$ deep in cores from water depths $<2500 \mathrm{~m}$ and only $2-3 \mathrm{~cm}$ at greater depths, and estimated bioturbation intensities similarly fall off with water depth. These values are much lower than the average SML of $\sim 10 \mathrm{~cm}$ in marine sediments elsewhere. It is unlikely that the present-day primary production in the eastern Mediterranean can sustain any structured macrobenthic activity at $>2500 \mathrm{~m}$. The historical layer of some box-cores and the Pleistocene hardgrounds collected in the Cleft area (Mediterranean Ridge) do, however, record a macrobenthic activity that is apparently more intense than at present, which may be related to higher primary production of the Pleistocene glacial intervals. In contrast with most areas of the present-day deep eastern Mediterranean which depend on surface primary production based on photosynthesis, a relatively dense and diversified macrobenthic community based on chemosynthesis has been recognised at depths $>1100 \mathrm{~m}$ on the Napoli Dome mud volcano in the Olimpi area, and on the Kazan and other mud volcanoes in the Anaximander Mountains.
\end{abstract}

Key words: deep macrobenthos, eastern Mediterranean, ${ }^{210} \mathrm{~Pb}$ profiles, surface mixed layer, trace fossils, chemosynthesis, sapropels, Pleistocene.

RESUMEN: INDICACIONES DE BAJA ACTIVIDAD EN EL MACROBENTOS DE SEDIMENTOS PROFUNDOS EN EL MEDITERRÁNEO ORIENTAL. - En el Mediterráneo oriental los flujos de materia orgánica desde las aguas superficiales oligotróficas hasta las aguas profundas son poco conocidos y en general hay poca información sobre la actividad del macrobentos en el fondo del mar. La evidencia de la actividad macrobentónica puede ser directa, a través de los organismos vivos o de los restos de esqueletos autóctonos, o indirecta, a través de la bioturbación y fósiles. La evidencia de la actividad biológica en los sedimentos profundos del Mediterráneo oriental se ha evaluado y comparado por medio de los perfiles del ${ }^{210} \mathrm{~Pb}$ provinentes de muestreos con box-corer y dragas tomados en varios puntos del dorsal Mediterráneo, al SO y S de Creta (entre 1783 y $3655 \mathrm{~m}$ ). Se espera que la actividad biológica de estos fondos alejados de la plataforma continental dependa principalmente de la producción primaria de las aguas superficiales. Los resultados muestran que el macrobentos actual y los fósiles son generalmente escasos, especialmente en fondos superiores a los $2500 \mathrm{~m}$. Estas observaciones se basan en la distribución del exceso de ${ }^{210} \mathrm{~Pb}$ que se ha encontrado en en la capa superficial de mezcla del sedimento, inferior a $6 \mathrm{~cm}$ de grosor, en los cores de aguas inferiores a $2500 \mathrm{~m}$; y de solo 2-3 cm a mayor profundidad. La estimación de la intensidad de la bio-perturbación también cae de manera parecida con la profundidad. Estos valores son mucho más bajos que la media de la capa superficial de mezcla de unos $10 \mathrm{~cm}$ en los sedimentos marinos de otras zonas. Es probable que la producción primaria actual en el Mediterráneo oriental no pueda soportar ninguna actividad macrobentónica estruturada a más de $2500 \mathrm{~m}$. La capa histórica 
en algunos box-corer de los fondos duros del Pleistoceno muestreados en el área de Cleft registran, sin embargo, una catividad macrobentónica aparentemente más intensa que la actual, y que podría relacionarse con una producción primaria alta durante los intervalos interglaciales del Pleistoceno. Contrariamente a lo encontrado en la mayoría de las áreas actuales en el Mediterráneo oriental profundo, el cual depende de la producción primaria superficial basada en la fotosíntesis, en el volcán fangoso de Napoli Dome en el área de Olimpi, en el Kazan y otros volcanes fangosos de las montañas Anaximander, se ha encontrado una comunidad macrobentónica relativamente densa y diversificada basada en procesos quimiosintéticos.

Palabras clave: macrobentos profundo, Mediterráneo oriental, perfiles de ${ }^{210} \mathrm{~Pb}$, capa superficial mezclada, fósiles traza, quimiosíntesis, sapropeles, Pleistoceno.

\section{INTRODUCTION}

The Mediterranean is a semi-enclosed sea that acts as a concentration basin. At the Strait of Gibraltar its water budget deficit is compensated by the ingress of fresher Atlantic waters at the surface over an underlying denser and higher salinity outflow. This anti-estuarine circulation (Bethoux, 1979; Bryden, 1993) prevents nutrient accumulation in the Mediterranean basin, especially in the eastern subbasin west of the Straits of Sicily, thus causing oligotrophy (Bethoux, 1989). The actual fluxes and budget of organic matter to the deep eastern Mediterranean are still poorly known, but the carbon export from the euphotic layer to $1000 \mathrm{~m}$ depth is equivalent to about $10 \%$ in the western Mediterranean (Gulf of Lions) which is about 5 times higher than in the eastern Mediterranean (Cretan Sea); accordingly, chlorophyll-a concentrations are 2-3 times higher in the western basin than in the eastern basin at similar depths (Danovaro et al., 1999; Psarra et al., 2000). Abundance and diversity of benthic biomass decrease with water depth, and marine invertebrates are particularly scarce in water depths exceeding $2000 \mathrm{~m}$ (Fredj and Laubier, 1985; Hausmann et al., 2002).

Knowledge of the deep meiofauna is good compared with the limited information available on the macrobenthos. The density of metazoan meiofauna decreases with depth and there is evidence of a significant relationship between meiofauna density in eastern Mediterranean sediments and the amount of labile organic matter that is readily available to benthic consumers (Danovaro et al., 1995). The microbial activity in deep-sea sediments also appears to be regulated by the input of phytodetritus to the sediments (Boetius et al., 1996). Moreover, it has been shown that the bathymetrical succession of benthic foraminifers is determined by the organic flux, such that their habitat range reflects the west to east trend of increasing oligotrophy in the basin by a shallowing of upper or lower water depth limits (De Rijk et al., 2000).
The availability of oxygen is also an important parameter for understanding the distribution of benthic fauna on and in the sediments. Simulations of oxygen consumption in the deep waters of the eastern Mediterranean yield higher rates than those found in the Atlantic and Pacific, possibly related to the relatively high deep water temperatures which characterise the eastern Mediterranean, but ventilation is sufficient to ensure that the present deep waters of the eastern Mediterranean are well oxygenated (Bethoux, 1989; Souvermezoglou and Krasakopoulou, 1998; Roether and Well, 2001).

The benthic macrofauna of the deep eastern Mediterranean seems to be very sparse, with few exceptions (Fredj et al., 1992; Fiege et al., 2000). Due to its extreme scarcity, it is difficult to sample and is therefore poorly known. In the oligotrophic south Aegean Sea, over the continental slope of Crete, the macrobenthos distribution sharply decreases with depth and is limited by food availability, which in turn depends on the pelagic food web and its hydrological framework (Tselepides and Eleftheriou, 1992).

The macrobenthic activity in the eastern basin at sites far from the continental shelves is expected to depend mainly on the primary production from surface waters; therefore, its intensity should mirror the trophic quality of the sea water, in the present as in the past.

The eastern Mediterranean, one of the least productive seas in the world, has been defined as a marine desert (Azov, 1991). However, exceptionally high abundances of benthic biomass have been recorded in some trenches that channel fresh organic material from adjacent steep slopes (Boetius et al., 1996).

Evidence of macrobenthic activity can be direct, through recovery of living organisms or their autochthonous skeletal remains, or indirect through bioturbation and trace fossils.

In this work the downcore distribution of the natural radionuclide ${ }^{210} \mathrm{~Pb}_{\text {excess }}$ was used to assess the depth of modern sediment mixing due to bioturba- 
tion (e.g. Soetaert et al., 1996). ${ }^{210} \mathrm{~Pb}$ is supplied to the surface ocean from the atmosphere, following its production in the atmosphere from the decay of ${ }^{222} \mathrm{Rn}$ that has emanated from the continental landmasses (Turekian et al., 1977). Once deposited in the surface ocean, ${ }^{210} \mathrm{~Pb}$ is particle reactive, and traces surface ocean production (Moore and Dymond, 1988). Sinking organic material can absorb further ${ }^{210} \mathrm{~Pb}$ during descent through the ocean water column, where ${ }^{210} \mathrm{~Pb}$ is present from decay of ${ }^{226} \mathrm{Ra} .{ }^{210} \mathrm{~Pb}$ has a half-life of 22 years so its activity in sediments decays to $1 \%$ of its initial value in $\sim 130$ years. At a sediment accumulation rate of 3 $\mathrm{cm} \mathrm{ky}^{-1}$, which is typical for the deep eastern Mediterranean (van Sandtvoort et al., 1996), ${ }^{210} \mathrm{~Pb}_{\text {excess }}$ would therefore only be found in the uppermost 3-4 $\mathrm{mm}$ of the sediments in the absence of bioturbation. As a consequence of bioturbation, however, ${ }^{210} \mathrm{~Pb}_{\text {excess }}$ is mixed down to greater depths in oxic sediments by organisms foraging and feeding.

This paper reports the thickness of the ${ }^{210} \mathrm{~Pb}_{\text {excess }}$, SML as a function of the bioturbation at several deep eastern Mediterranean sites. These data are the framework for qualitative observations of direct and indirect evidence of macrobenthic activity in twenty-one box-cores and one dredge sample from oxic environments in different geological settings. A comparison is made with the intense macrobenthic activity based on chemosynthesis known to occur in the region of cold seep-associated mud volcanoes, and with the higher productivity that characterised the eastern Mediterranean during the glacial Pleistocene.

\section{METHODS}

The samples available for ${ }^{210} \mathrm{~Pb}_{\text {excess }}$ analysis were from box core sub-cores (Fig. 1; Table 1) that had been sliced at 0.5 or $1 \mathrm{~cm}$ resolution for geochemical purposes. Powdered samples of $\sim 1 \mathrm{~g}$ were leached with hot $6 \mathrm{~N} \mathrm{HCl}$ with a calibrated ${ }^{209} \mathrm{Po}$ tracer added. The Po isotopes were then plated on Ag planchettes by the method of Flynn (1968) for proxy determination of ${ }^{210} \mathrm{~Pb}$ via ${ }^{210} \mathrm{Po}$ by alpha spectrometry based on the known added activity of ${ }^{209} \mathrm{Po}$.

Formally, the specific activity (disintegrations per minute per gram, dpm $\mathrm{g}^{-1}$ ) of ${ }^{210} \mathrm{~Pb}_{\text {excess }}$ is the amount in excess of radioactive secular equilibrium with its radioactive parent ${ }^{226} \mathrm{Ra}$, i.e.

${ }^{210} \mathrm{~Pb}$ excess specific activity $=\left(\right.$ measured ${ }^{210} \mathrm{~Pb}$ specific activity) - (measured ${ }^{226} \mathrm{Ra}$ specific activity)

A simpler procedure is to assess ${ }^{226} \mathrm{Ra}$ specific activity from the ${ }^{210} \mathrm{~Pb}$ profile itself, by assuming that ${ }^{210} \mathrm{~Pb}_{\text {excess }}$ will only be present near the sediment surface, and that lower near-constant values of ${ }^{210} \mathrm{~Pb}$ at depth will correspond to detrital ${ }^{226} \mathrm{Ra}$ levels. This approximation is well suited to the leaching method used here to release ${ }^{210} \mathrm{~Pb}_{\text {excess }}$ without attempting to

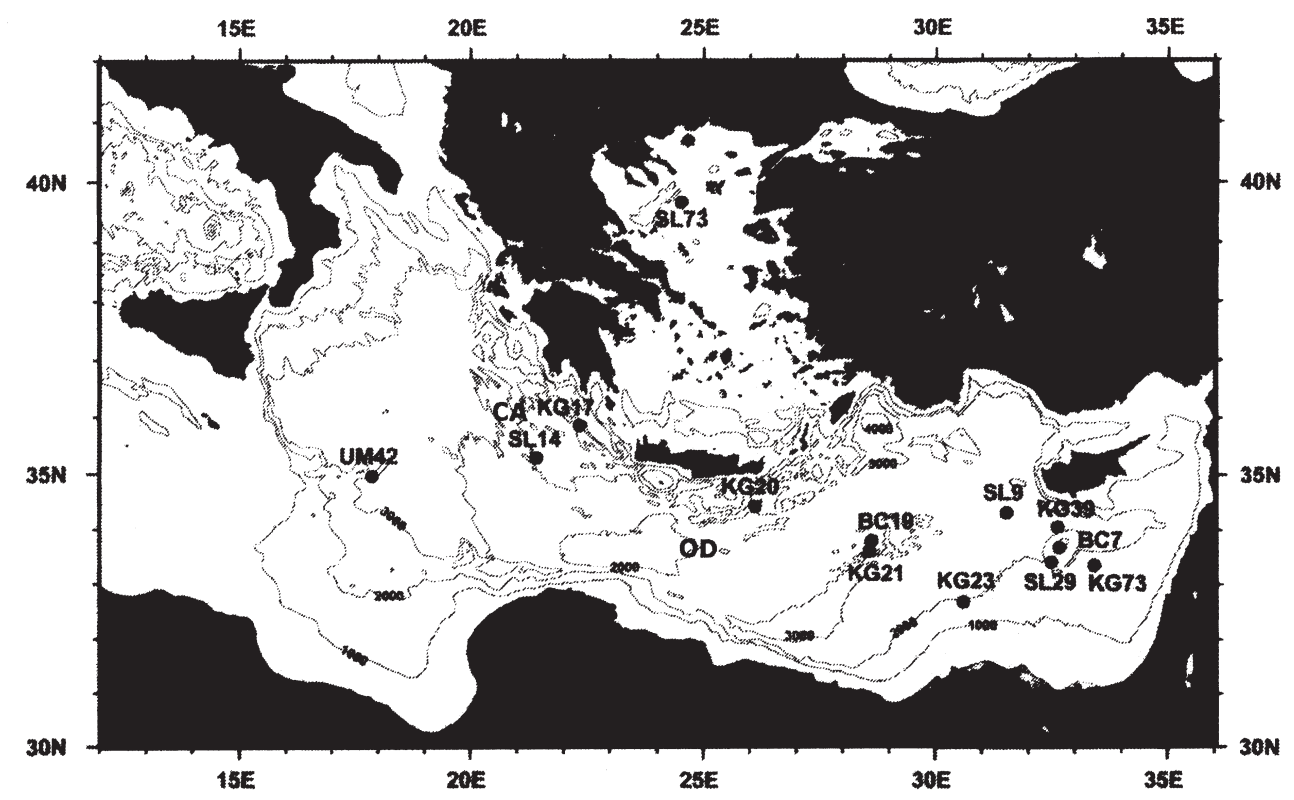

FIG. 1. - Map of the eastern Mediterranean Sea with the positions of the cores (see also Table 1) and location of the Cleft area (CA) and Olimpi Diapiric area (OD). Water depth contours are at $1000 \mathrm{~m}$ intervals. 
TABLE 1. - Details of the 13 cores studied for surface layer mixing by the ${ }^{210} \mathrm{~Pb}_{\text {excess }}$ method.

\begin{tabular}{|c|c|c|c|c|c|c|c|c|c|}
\hline Core & Latitude N & Longitude E & $\begin{array}{l}\text { Water depth } \\
\text { (m) }\end{array}$ & 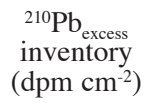 & $\begin{array}{c}{ }^{210} \mathrm{~Pb}_{\text {excess }} \\
\text { flux } \\
\left(\mathrm{dpm} \mathrm{cm}^{-2} \mathrm{y}^{-1}\right)\end{array}$ & $\begin{array}{c}\text { Exponential } \\
\text { best-fit } A_{0} \\
\left(\mathrm{dpm} \mathrm{g}^{-1}\right)\end{array}$ & $\begin{array}{c}\text { Exponential } \\
\text { best-fit } \\
\text { exponent }\end{array}$ & $\begin{array}{c}\mathrm{Db} \\
\left(\mathrm{cm}^{2} \mathrm{y}^{-1}\right)\end{array}$ & $\begin{array}{c}\text { Surface mixed } \\
\text { layer depth } \\
(\mathrm{cm})\end{array}$ \\
\hline BC7 & $33^{\circ} 39^{\prime} 23^{\prime \prime}$ & $32^{\circ} 40^{\prime} 02^{\prime \prime}$ & 893 & 6.30 & 0.20 & 13.88 & -1.386 & 0.014 & 3.3 \\
\hline UM42 & $34^{\circ} 57^{\prime} 14^{\prime \prime}$ & $17^{\circ} 51^{\prime} 45^{\prime \prime}$ & 1375 & 12.57 & 0.40 & 17.10 & -0.779 & 0.048 & 5.9 \\
\hline SL29 & $33^{\circ} 23^{\prime} 21^{\prime \prime}$ & $32^{\circ} 30^{\prime} 11^{\prime \prime}$ & 1587 & 13.25 & 0.42 & 22.23 & -1.126 & 0.022 & 4.1 \\
\hline SL9 & $34^{\circ} 17^{\prime} 10^{\prime \prime}$ & $31^{\circ} 31^{\prime} 22^{\prime \prime}$ & 2302 & 19.29 & 0.61 & 12.16 & -0.512 & 0.114 & 9.0 \\
\hline BC19 & $33^{\circ} 47^{\prime} 51^{\prime \prime}$ & $28^{\circ} 36^{\prime} 30^{\prime \prime}$ & 2750 & 13.78 & 0.43 & 48.03 & -2.171 & 0.005 & 2.1 \\
\hline SL114 & $35^{\circ} 17^{\prime} 14^{\prime \prime}$ & $21^{\circ} 24^{\prime} 31^{\prime \prime}$ & 3390 & 18.46 & 0.58 & 62.29 & -2.340 & 0.005 & 2.0 \\
\hline SL73 & $39^{\circ} 39^{\prime} 40^{\prime \prime}$ & $24^{\circ} 30^{\prime} 39^{\prime \prime}$ & 339 & 16.41 & 0.52 & - & - & - & - \\
\hline KG17 & $35^{\circ} 51^{\prime} 21^{\prime \prime}$ & $22^{\circ} 20^{\prime} 07^{\prime \prime}$ & 4617 & 24.63 & 0.78 & 59.89 & -1.475 & 0.012 & 3.1 \\
\hline KG20 & $34^{\circ} 25,20^{\prime \prime}$ & $26^{\circ} 05^{\prime} 56^{\prime \prime}$ & 2412 & 16.44 & 0.52 & 14.01 & -0.746 & 0.053 & 6.2 \\
\hline KG21 & $33^{\circ} 36^{\prime} 13^{\prime \prime}$ & $28^{\circ} 34^{\prime} 13^{\prime \prime}$ & 2967 & 13.1 & 0.41 & 63.71 & -2.595 & 0.004 & 1.8 \\
\hline KG23 & $32^{\circ} 40^{\prime} 50^{\prime \prime}$ & $30^{\circ} 35,44^{\prime \prime}$ & 1907 & 19.2 & 0.60 & 30.61 & -1.127 & 0.022 & 4.1 \\
\hline KG37 & $33^{\circ} 19^{\prime} 58^{\prime \prime}$ & $33^{\circ} 24^{\prime} 45^{\prime \prime}$ & 1822 & 39.35 & 1.24 & 45.64 & -0.826 & 0.043 & 5.6 \\
\hline KG39 & $34^{\circ} 02^{\prime} 07^{\prime \prime}$ & $32^{\circ} 37^{\prime} 34^{\prime \prime}$ & 2548 & 25.24 & 0.80 & 47.51 & -1.191 & 0.020 & 3.9 \\
\hline
\end{tabular}

dissolve the sediments to ensure release of all ${ }^{210} \mathrm{~Pb}$ and ${ }^{226} \mathrm{Ra}$.

Assuming a constant bioturbation rate $\mathrm{D}_{\mathrm{b}}\left(\mathrm{cm}^{2}\right.$ $\left.\mathrm{y}^{-1}\right)$ in the SML, a constant sedimentation rate $\omega(\mathrm{cm}$ $\left.\mathrm{y}^{-1}\right)$ and constant dry sediment bulk density $\rho(\mathrm{g}$ $\left.\mathrm{cm}^{-3}\right), \mathrm{D}_{\mathrm{b}}$ is evaluated by fitting the following equation to the ${ }^{210} \mathrm{~Pb}$ profiles using a least squares best fit of ${ }^{210} \mathrm{~Pb}_{\text {excess }}$ specific activity (A) on depth (z):

$$
A=A_{0} \exp \left[\left(\left(\omega-\left(\omega^{2}+4 \lambda D_{b}\right)^{0.5}\right) / 2 D_{b}\right) z\right]
$$

with boundary conditions $\mathrm{A}=\mathrm{A}_{0}$ at $\mathrm{z}=0$ and $\mathrm{A} \rightarrow 0$ as $\mathrm{z} \rightarrow \infty$.

This solution assumes that the SML is greater than the depth ${ }^{210} \mathrm{~Pb}_{\text {excess }}$ penetration, and is in effect equal to infinity (e.g. DeMaster and Cochran, 1982). This procedure gives sediment mixing information on a $\sim 100$ y time scale, and on this time scale the SML depth is evaluated as the depth at which the best-fit $\mathrm{A}_{0}$ value falls to $\mathrm{A}_{0} / 100$.

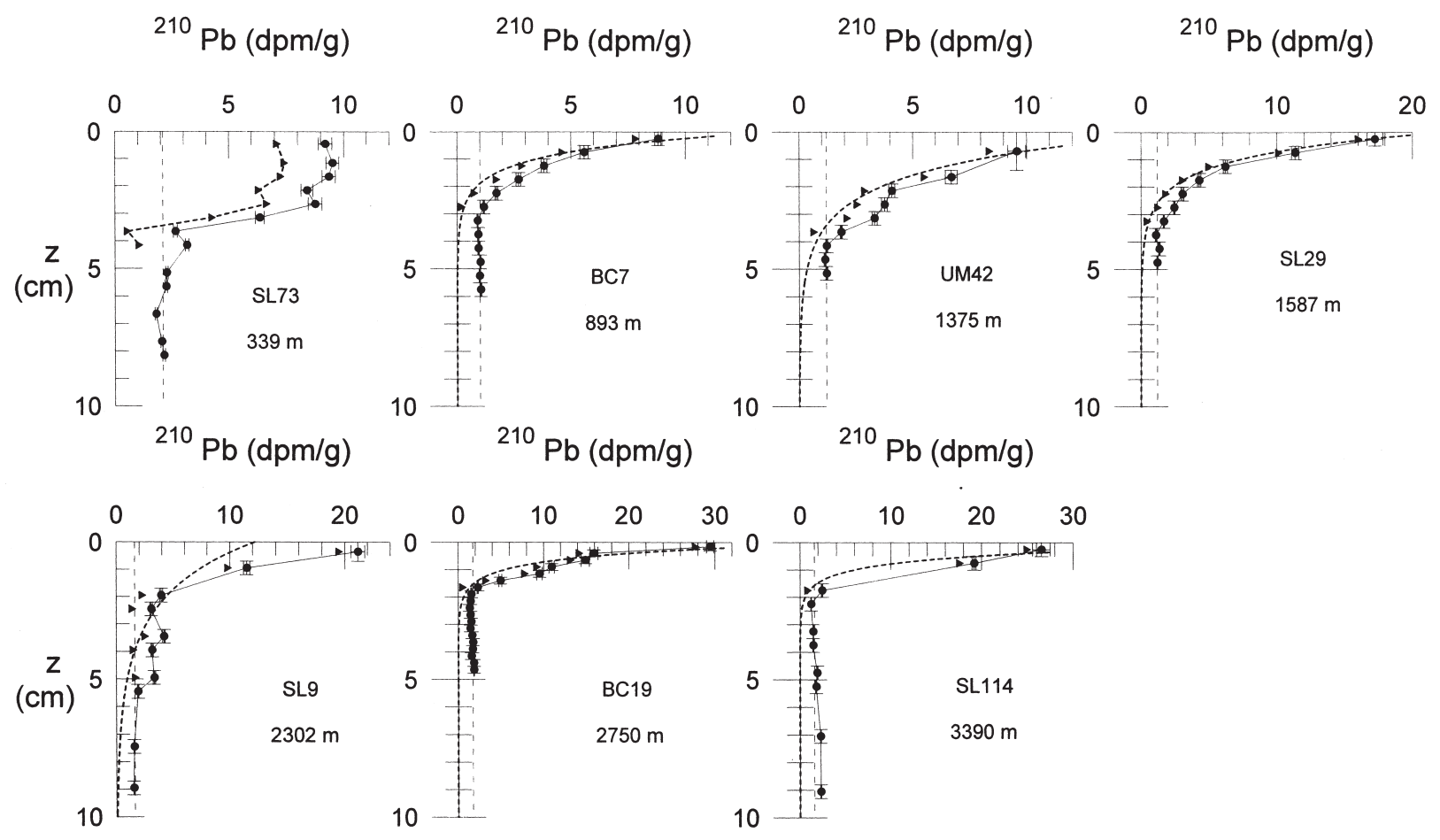

FIG. 2. - Total ${ }^{210} \mathrm{~Pb}$ (filled circles) and inferred ${ }^{210} \mathrm{~Pb}_{\text {excess }}$ (triangles) specific activities for seven cores collected on the "Sapropels and Paleoceanography" programme. The activity level taken to represent detrital ${ }^{226} \mathrm{Ra}$ and ${ }^{210} \mathrm{~Pb}$ is shown as the dashed line; this value was subtracted from total ${ }^{210} \mathrm{~Pb}$ to obtain ${ }^{210} \mathrm{~Pb}_{\text {excess }}$. The exponential best fit of ${ }^{210} \mathrm{~Pb}_{\text {excess }}$ activity on depth is shown as the dashed curve. 


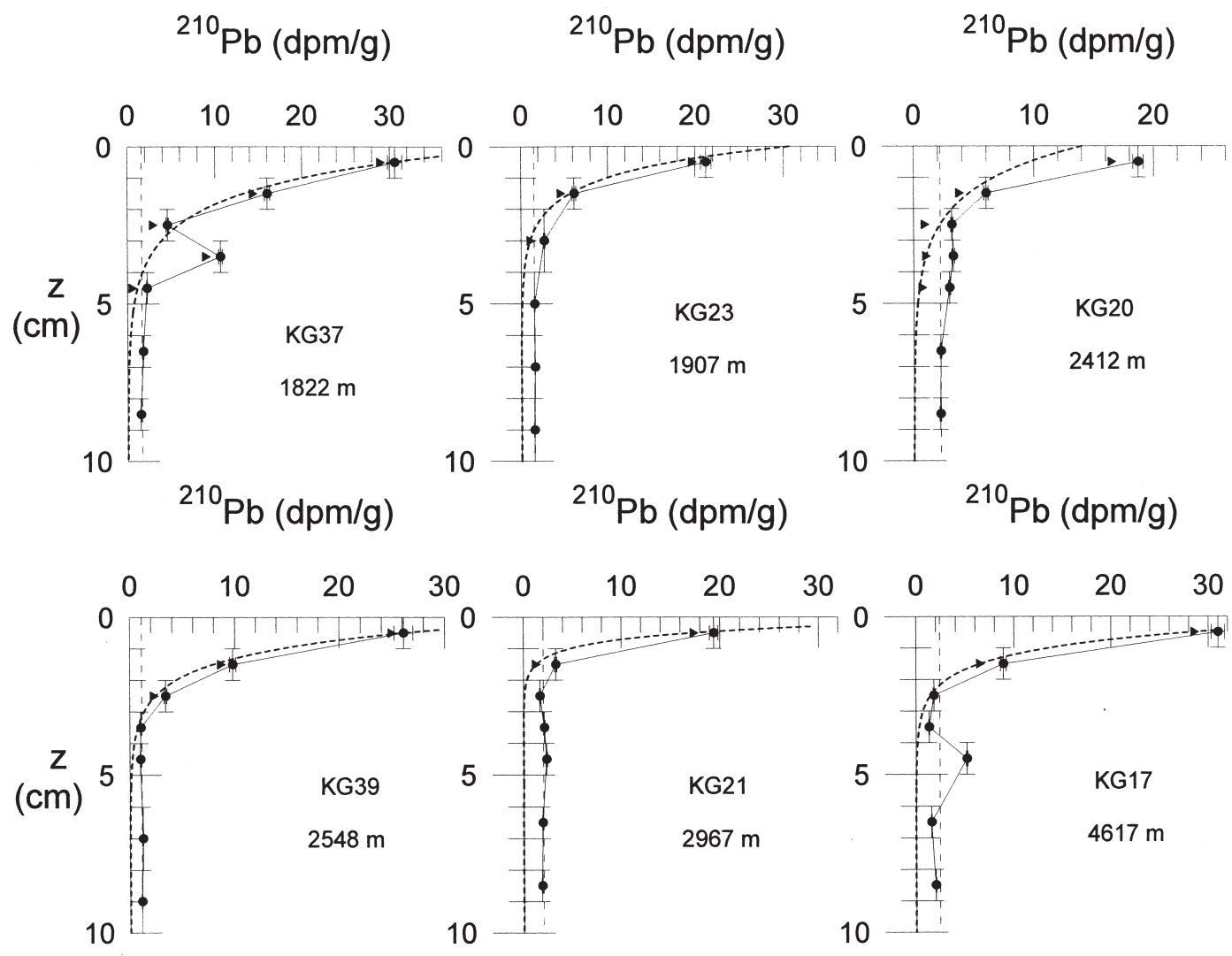

FIG. 3. - Total ${ }^{210} \mathrm{~Pb}$ (filled circles) and inferred ${ }^{210} \mathrm{~Pb}_{\text {excess }}$ (triangles) specific activities for six cores collected on R.V. Meteor cruise $25 / 1$. The activity level taken to represent detrital ${ }^{226} \mathrm{Ra}$ and ${ }^{210} \mathrm{~Pb}$ is shown as the dashed line; this value was subtracted from total ${ }^{210} \mathrm{~Pb}$ to obtain ${ }^{210} \mathrm{~Pb}_{\text {excess. }}$ The exponential best fit of ${ }^{210} \mathrm{~Pb}_{\text {excess }}$ activity on depth is shown as the dashed curve.

\section{RESULTS}

The total ${ }^{210} \mathrm{~Pb}$ specific activity data and the exponential best fits for the deduced ${ }^{210} \mathrm{~Pb}_{\text {excess }}$ data for the cores analysed are presented as Figures 2 and 3 . For most cores, the ${ }^{210} \mathrm{~Pb}_{\text {excess }}$ data conform satisfactorily to an exponential. An exception is the shallowest core studied (SL 73 from the Aegean Sea), in which the sediments are completely mixed over $0-3$ $\mathrm{cm}$ with mixing falling off between 3 and $4.5 \mathrm{~cm}$, and in this case the mixing is clearly layered and of different intensity in different depth zones. In two other cases (KG37, KG17) there are single data points at depth that clearly exceed the exponential trend from the remainder of the ${ }^{210} \mathrm{~Pb}_{\text {excess }}$ data in the core.

Most of the box-cores show an uppermost mixed layer $<6 \mathrm{~cm}$ thick, probably related to bioturbation by meiobenthic organisms (Fig. 4).

Out of the twenty-one box-cores collected in the eastern Mediterranean during the Paleoflux cruises, a living polychaete with an agglutinated tube was observed in only one core from the Cleft area at $2835 \mathrm{~m}$ depth. One empty polychaete tube was

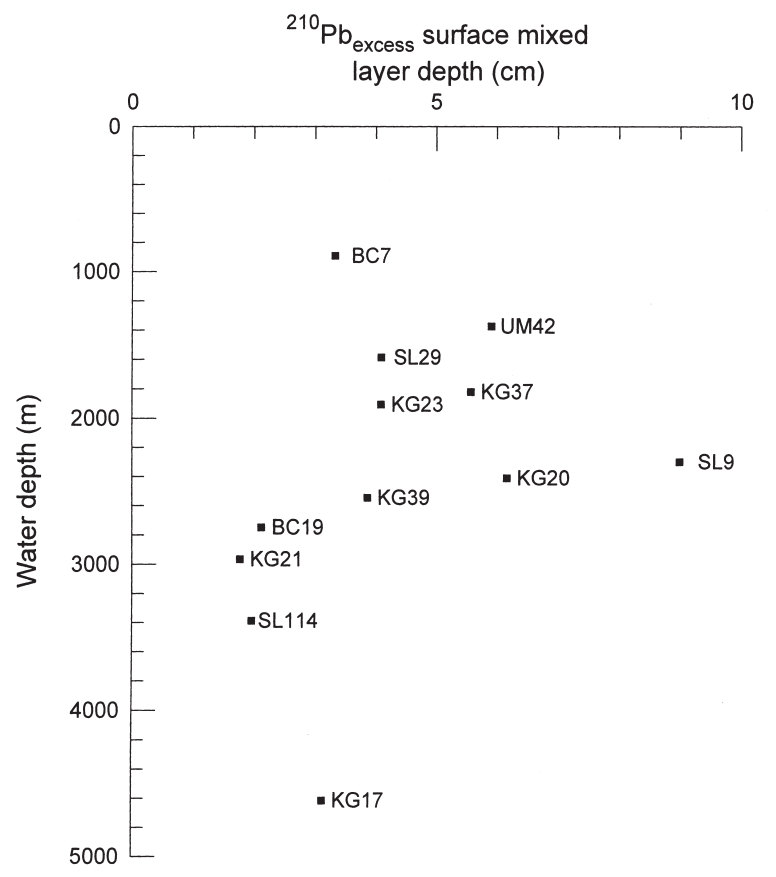

FIG. 4. - Surface mixed layer depths as calculated from the ${ }^{210} \mathrm{~Pb}_{\text {excess }}$ activity profiles as a function of core water depth. 


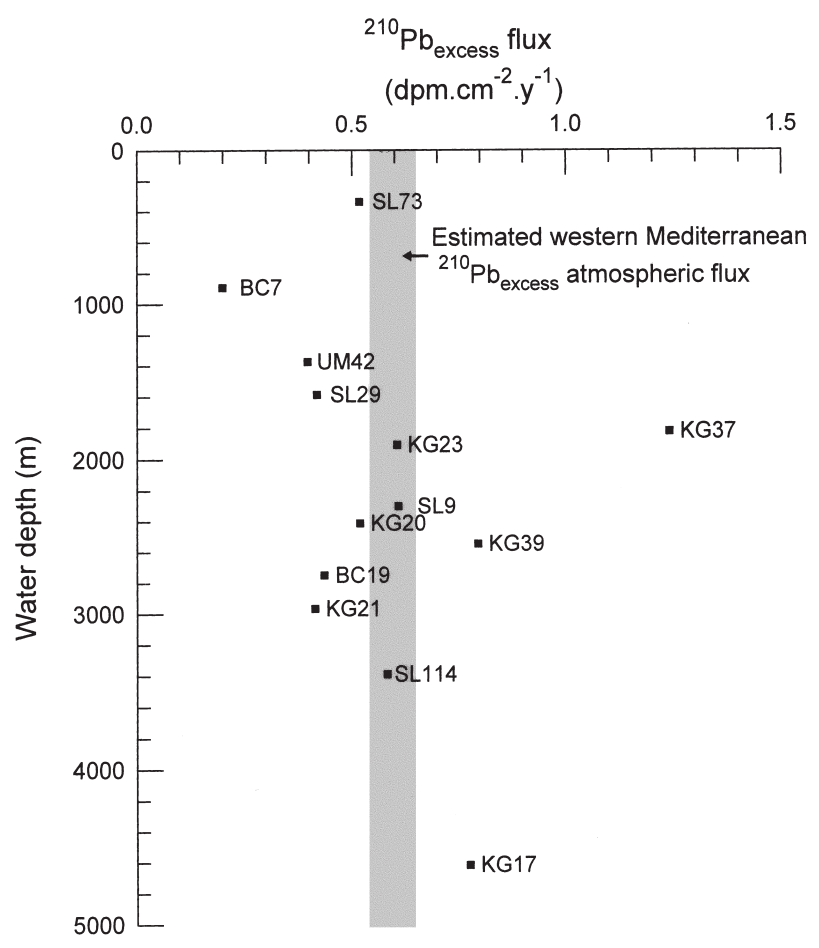

FIG. 5. - Steady state flux of ${ }^{210} \mathrm{~Pb}_{\text {excess }}$ deposited in each core as a function of water depth. The range estimated for western Mediterranean atmospheric deposition by Radakovitch et al. (1999) is shaded.

observed at $20 \mathrm{~cm}$ depth in a core from $3498 \mathrm{~m}$ depth, NW of the Urania anoxic basin (Basso and Corselli, 1998). Bioturbation as evidenced by trace fossils or mottled sediments in the cores seems to be more prevalent about $10-20 \mathrm{~cm}$ below the top (historical layer) of box-cores collected deeper than $2000 \mathrm{~m}$.

In a few box-cores (UM94 cruise $\mathrm{BC} 40, \mathrm{BC} 35$, BC15, BC29 and BC30) Chondrites-type trace fossils were observed, either in association with the sapropel layer S-1 (about 8000 yrs BP) or with the Etna eruption tephra layer (2000 yrs BP). Several slabs of a Pleistocene hardground, intensively bioturbated (Chondrites, Planolites and Paleophycus cf. heberti (Pemberton and Frey, 1982), were collected by dredging along the slope of Mound II, in the Cleft area (Basso and Corselli, 1998).

\section{DISCUSSION}

In absence of visible evidence of benthic activity in the form of trace fossils, which is the general case in the deep eastern Mediterranean, the thickness of the SML caused by bioturbation as revealed by the ${ }^{210} \mathrm{~Pb}_{\text {excess }}$ profiles was adopted as a measure of bio- turbation (Fig. 4). For most of the cores studied, the ${ }^{210} \mathrm{~Pb}_{\text {excess }} \mathrm{A}_{0} / 100 \mathrm{SML}$ layer is $<6 \mathrm{~cm}$, and for several-particularly those from the deepest water depths $>2500 \mathrm{~m}-$ it is $2-3 \mathrm{~cm}$. Like the SML depth (Fig. 4), the estimated bioturbation intensities $\left(D_{b}\right)$ are also higher at $>0.015 \mathrm{~cm}^{2} \mathrm{y}^{-1}$ in cores from water depths $<2700 \mathrm{~m}$ than in cores from $>2700 \mathrm{~m}$, where $D_{b}$ is $<0.015 \mathrm{~cm}^{2} \mathrm{y}^{-1}$ (Table 1 ). In comparison with marine sediments elsewhere, both the SML thickness and the $D_{b}$ values observed here (Tab. 1) are low. From consideration of a large body of data in which bioturbation was assessed by a variety of methods in a wide range of sediments, Boudreau (1994, 1998) has shown that the mean SML in marine sediments is $9.8 \pm 4.5 \mathrm{~cm}$ ( $1 \sigma$ error).

Different combinations of factors have been invoked to explain differences in the SML thickness observed in the world's oceans. On the Oman margin (400-1000 m), Smith et al. (2000) found a mean SML thickness of $4.6 \mathrm{~cm}$ on a transect through the oxygen minimum zone, which contrasted with welloxygenated waters of the Atlantic and Pacific Oceans where the SML was twice as thick. Smith et al. (1993) and Smith and Rabouille (2002) hypothesised that bioturbation in the SML was driven by the flux of organic matter to the sea floor, and that recently-sedimented particles of high food value were mixed by deposit feeders at higher rates than older, food-poor particles. Trauth et al. (1997) estimated that the SML thickness increased by $2 \mathrm{~cm}$ for every 1 gram of carbon $\mathrm{m}^{-2} \mathrm{y}^{-1}$ deposited on the sea

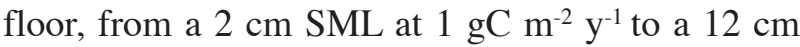
SML at $6 \mathrm{gC} \mathrm{m}^{-2} \mathrm{y}^{-1}$. Similarly, Legeleux et al. (1994) found that the intensity and SML depth of bioturbation both decreased along an offshore Atlantic transect chosen to underlie a range of surface ocean productivities ranging from eutrophic to oligotrophic. Only the most oligotrophic and deepest site on this transect provided ${ }^{210} \mathrm{~Pb}$ profiles similar to those seen here in the eastern Mediterranean. The deposition flux to the seafloor at $4.4 \mathrm{~km}$ water depth at this oligotrophic site was estimated as only $0.34 \mathrm{gC} \mathrm{m}^{-2} \mathrm{y}^{-1}$ (Legeleux et al., 1996).

Subsurface maxima in ${ }^{210} \mathrm{~Pb}_{\text {excess }}$ in the SML, as evident in cores SL9, KG17 and KG37, have also been noted elsewhere, and have been ascribed to local injection of surficial material at depth, for example as infill of large burrows (e.g. Smith et al., 1987; Soetaert et al., 1996; Thomson et al., 2000). This local or impulse bioturbation contrasts with the reworking by multiple small-scale events (termed non-local mixing) that approximate diffusive mixing 
and result in an exponential decrease in ${ }^{210} \mathrm{~Pb}_{\text {excess }}$ specific activity profiles with depth.

As stated above, the overall ${ }^{210} \mathrm{~Pb}_{\text {excess }}$ flux to the sediments from the water column comprises the atmospheric input to the surface ocean and an additional increment scavenged from the water column by settling particulate matter. The inventory in the sediments is assessed as:

$$
\mathrm{I}=\Sigma\left(\mathrm{A}_{\mathrm{i}} \rho_{\mathrm{i}} \Delta \mathrm{z}_{\mathrm{i}}\right)
$$

where I is the sediment inventory $\left(\mathrm{dpm} \mathrm{cm}^{-2}\right)$

$A_{i}$ is the ${ }^{210} \mathrm{~Pb}_{\text {excess }}$ activity in dpm $\mathrm{g}^{-1}$ for sample $\mathrm{i}$

$\rho_{i}$ is the dry bulk density $\left(\mathrm{g} \mathrm{cm}^{-3}\right.$; assumed constant $=0.7 \mathrm{~g} \mathrm{~cm}^{-3}$ )

$\Delta z_{\mathrm{i}}$ is the sample thickness $(\mathrm{cm})$.

Assuming steady state supply and decay of ${ }^{210} \mathrm{~Pb}_{\text {excess }}$ to the sea floor, inventory and flux are related as:

$$
\mathrm{J}=\lambda \mathrm{I}
$$

where $J$ is the ${ }^{210} \mathrm{~Pb}_{\text {excess }}$ flux $\left(\mathrm{dpm} \mathrm{cm}^{-2} \mathrm{y}^{-1}\right)$ and $\lambda$ is the decay constant of ${ }^{210} \mathrm{~Pb}\left(\mathrm{y}^{-1}\right)$.

Radakovitch et al. (1999) assessed various different measurements of the ${ }^{210} \mathrm{~Pb}_{\text {excess }}$ atmospheric flux alone (mainly for the western Mediterranean basin) and adopted a mean value of $0.59 \pm 0.06 \mathrm{dpm}$ $\mathrm{cm}^{-2} \mathrm{y}^{-1}$, although a lower value of $0.48 \mathrm{dpm} \mathrm{cm}^{-2} \mathrm{y}^{-1}$ has also been measured (Sanchez-Cabeza et al., 1999). The mean ${ }^{210} \mathrm{~Pb}_{\text {excess }}$ flux to the sea floor for all 13 cores studied here is $0.58 \mathrm{dpm} \mathrm{cm}^{-2} \mathrm{y}^{-1}$, which agrees perfectly with Radakovitch's estimate. Nevertheless, with the exceptions of cores BC7 and $\mathrm{KG} 37$, which appear off-trend, there is a loosely defined trend in the data of an increase from $0.4 \mathrm{dpm}$ $\mathrm{cm}^{-2} \mathrm{y}^{-1}$ between core UM42 at $1.4 \mathrm{~km}$ water depth to $0.8 \mathrm{dpm} \mathrm{cm}^{-2} \mathrm{y}^{-1}$ for core KG17 at $4.6 \mathrm{~km}$ (Fig. 5). This is the expected pattern for an additional progressive uptake of ${ }^{210} \mathrm{~Pb}_{\text {excess }}$ from the ${ }^{226} \mathrm{Ra}$ in the water column, and Figure 5 is interpreted to represent a somewhat lower atmospheric input flux for the eastern basin than that determined by Radakovitch et al. (1999), coupled with an additional ${ }^{210} \mathrm{~Pb}_{\text {excess }}$ uptake from the water column (e.g. Cochran et al., 1990; Thomson et al., 1993). To model this situation satisfactorily would require parallel ${ }^{210} \mathrm{~Pb}$ and ${ }^{226} \mathrm{Ra}$ concentration data for the deep Mediterranean water column, which do not appear to be available. These would be expected to be quite unlike open Atlantic ${ }^{226} \mathrm{Ra}$ and ${ }^{210} \mathrm{~Pb}$ water column profiles, however, because the Mediterranean is a concentration basin in which the deep waters are formed from regularly-replenished input Atlantic surface water (Schmidt and Reyss, 1996).

The occurrence of living or dead macrobenthos is very rare in the deep eastern Mediterranean, despite the fact that some phyla are relatively well diversified in shallow environments (Laubier and Emig, 1993; Koutsoubas et al., 2000; Sorbe and Galil, 2002). In contrast with this "desert" on the deep sea floor, much richer communities that are sustained by chemosynthesis have been described recently at cold-seep sites (Corselli and Basso, 1996; Aloisi et al., 2000; Salas and Woodside, 2002).

The Mediterranean Ridge is an accretionary prism in the eastern Mediterranean Sea that is generated by the convergence of the African and European plates. The related crustal deformation drives the circulation of sulphidic and methane-rich fluids that are expelled from the pressurised sediments (Camerlenghi et al., 1992; Cita et al., 1994; Corselli et al., 1996) and mud volcanoes are formed by intrusion of overpressured mud- and gas-charged pore fluids that reach the sea floor (Brown, 1990). Gas expands and rises up through the surface sediments, giving rise to the hydrocarbon gas emissions that are termed cold seeps. On a worldwide basis, cold seeps are located at depths ranging between 400 and $6000 \mathrm{~m}$ in different geological contexts, on both passive and active continental margins. Methane- or sulphide-rich fluids are the main source of energy for chemoautotrophic bacteria, endosymbionts to many bivalves (Vesicomyidae, Mytilidae, Solemyidae, Thyasiridae, Lucinidae), Pogonophora worms and some sponges (Sibuet and Olu, 1998).

Cold seeps in the deep eastern Mediterranean have been identified on the mud volcanoes of the Olimpi area (south of Crete) and of the Anaximander Mountains (south of Turkey) at water depths greater than $1600 \mathrm{~m}$. The associated coldseep fauna includes Lucinidae, Vesicomyidae, and vestimentiferans of the genus Lamellibrachia.

The modern eastern Mediterranean deep sea floor desert also appears to contrast with the Pleistocene paleoenvironment. It was noted some decades ago that the molluscan association recovered at depths ranging from 2300 to $4210 \mathrm{~m}$ in the Ionian Sea was extremely poor (Di Geronimo, 1974) and only a few specimens of living Yoldiella philippiana (Nyst, 1845), Benthonella tenella (Jeffreys, 1869) and Benthomangelia macra (Watson, 1881) could be separated from about $400 \mathrm{~kg}$ of dredged 
sediments. In contrast, the molluscan shell assemblages of the same samples were more diversified (17 species), and probably much older (upper Pleistocene), since the sedimentation rate in the sampled area is very low.

The contrast between a poor present-day deep association and a richer Pleistocene fossil record was later observed also in other phyla, such as scleractinians and serpulid polychaetes (Zibrowius, 1987; Barrier et al., 1989). The explanation focused on a pre-Holocene scenario with deep Mediterranean waters colder than at present, allowing a deep Atlantic fauna to colonise the Mediterranean and to be sustained by a higher nutrient input (Zibrowius, 1981; Taviani and Colantoni, 1984).

Due to the different hydrological and climatic conditions, the chemical and biological environments in the eastern and western Mediterranean basins were decoupled at least in some intervals (Weldeab et al., 2003). The deep-sea record of the eastern Mediterranean is characterised by the existence of numerous (several dozen) individual layers of green to black-coloured pelagic sediments rich in organic carbon, known as sapropels (Kidd et al., 1978), which are one to several centimetres thick and can be laminated. Sapropel deposition is considered to be a synchronous regional phenomenon. The distribution of sapropels is correlated with maxima of the orbital insolation monsoon index, which is a function of precessional insolation anomalies (Rossignol-Strick, 1983; Hilgen, 1991). A more intense summer monsoon would lead to more humid conditions in tropical Africa and along the borderlands of the eastern Mediterranean, with a consequent increase in continental runoff. Schilman et al. (2001) provided evidence of a strong correlation between eastern Mediterranean productivity fluctuations and Nile flood fluctuations, in turn driven by the periodic monsoonal activity over the Nile headwaters. The detailed mechanism for sapropel formation is still under debate, but there is a general consensus that a combination of factors including enhanced productivity and a low oxygen level in deep waters allow a preferential preservation of organic carbon in the sediments (Cita and Corselli, 1993; Emeis et al., 1996; Emeis and Sakamoto, 1998; Martinez-Ruiz et al., 2000). A tentative chain of events culminating in sapropel deposition has recently been proposed: an enhanced carbon burial driven by increased rates of marine productivity produces a corresponding increase in oxygen consumption in deep water and results in bottom anoxia.
Since sapropel deposition in the deep eastern Mediterranean is periodical and synchronous over the entire basin, the hypothesis of an external forcing (by precessional insolation variations and enhanced terrestrial runoff) for the phenomenon is conceivable (Emeis et al., 1996).

Sapropels are not usually bioturbated, but where bioturbation occurs it is from the top down. A relative abundance of trace fossils-mainly Chondrites-across and above some sapropel boundaries have been documented in ODP Leg 160 cores (Emeis et al., 1996). Chondrites producers are organisms with an opportunistic behaviour, being the first to make burrows after a sudden change in the sedimentation rate and an increase in the oxygen content of the pore waters (Savrda and Bottjer, 1986). Opportunistic ichnotaxa are usually identified in low diversity trace fossil associations and in sediment deposited under extreme environmental conditions (Ekdale, 1985; D'Alessandro et al., 1986). Chondrites-type trace fossils boring the sapropels of the deep eastern Mediterranean top down are evidence of enhanced macrobenthic activity following the restoration of oxic conditions in organic matter-enriched bottom sediments.

\section{CONCLUSIONS}

The Mediterranean, a semi-enclosed sea with relatively shallow sills separating distinct sub-basins, is characterised by an anti-estuarine circulation, which creates a nutrient desert in its eastern basin. As a consequence of nutrient limitation, the primary production based on photosynthesis is insufficient to sustain a well-structured macrobenthic community in offshore areas of the eastern Mediterranean at a depth $>2500 \mathrm{~m}$. This conclusion, based on direct observations and literature data, is supported by the thin $(<6 \mathrm{~cm})$ SMLs defined by ${ }^{210} \mathrm{~Pb}_{\text {excess }}$ core profiles, which record the sediment mixing from biological activity. Moreover, given the rare occurrence of macrobenthic fauna in the deep eastern Mediterranean, the bioturbation inferred from the thickness of the SML obtained from ${ }^{210} \mathrm{~Pb}_{\text {excess }}$ profiles is likely to be due to meiobenthos rather than to macrobenthic activity. An extremely scarce macrobenthos, which depends on photosynthesis-based surface ocean primary production, is therefore the general rule for the deep eastern Mediterranean.

As exceptions to this rule, two different contrasting situations are highlighted. 
The first is represented by the relatively rich, chemosynthetically sustained cold-seep communities localised at sites of gas emission that are controlled by active, regional geological processes.

The second relates to past environmental conditions: fossil macrobenthic remains and trace fossils recorded in a historical layer of box-cores are evidence of a Pleistocene deep Mediterranean in which the macrobenthic activity may have been more intense than today. In particular, the deepest areas of the more confined eastern basin had an amplified response to climatic changes as recorded by the periodical sapropel deposition. The restoration of oxic deep-water conditions after the events of bottom anoxia provided an exceptional organic carbon resource, which locally sustained an active macrobenthic fauna.

\section{ACKNOWLEDGEMENTS}

We thank G.J. de Lange and M. Krom for core samples for this investigation. We are grateful to three anonymous referees for their comments and useful suggestions. This work was partly supported by the EU Marine Science and Technology projects "Paleoflux" and "Sapropels And Paleoceanography" (SAP) and a research grant of Milan University to D.B.

\section{REFERENCES.}

Aloisi, G., C. Pierre, J.-M. Rouchy, J.-P. Foucher, J. Woodside and the MEDINAUT Scientific Party. - 2000. Methane-related authigenic carbonates of eastern Mediterranean Sea mud volcanoes and their possible relation to gas hydrate destabilisation. Earth Planet. Sci. Lett., 184: 321-338.

Azov, Y. - 1991. Eastern Mediterranean - a marine desert. Mar. Poll. Bull., 23: 225-232.

Barrier, P., I. Di Geronimo, C. Montenat, M. Roux and H. Zibrowius. - 1989. Presence de faunes bathyales atlantiques dans le Pliocene et le Pleistocene de Méditerranée (detroit de Messine, Italie). Bull. Soc. Geol. France, 8e, 5(4): 787-796.

Basso, D. and C. Corselli. - 1998. Trace fossils and bioturbation in the Eastern Mediterranean. Ist. Lomb. (Rend. Sc.), B 129: 365-381.

Bethoux, J.P. - 1979. Budgets of the Mediterranean Sea. Their dependence on the local climate and the characteristics of the Atlantic waters. Oceanol. Acta, 2: 157-163.

Bethoux, J.P. - 1989. Oxygen consumption, new production, vertical advection and environmental evolution in the Mediterranean Sea. Deep-Sea Res., 36: 769-781.

Boetius, A., S. Scheibe, A. Tselepides and H. Thiel. - 1996. Microbial biomass and activities in deep-sea sediments of the Eastern Mediterranean: trenches are benthic hotspots. Deep-Sea Res., 43(9): 1439-1460.

Boudreau, B.P. - 1994. Is burial velocity a master parameter for bioturbation? Geochim. Cosmochim. Acta, 58: 1243-1249.

Boudreau, B.P. - 1998. Mean mixed depth of sediments: The wherefore and the why. Limnol. Oceanogr., 43: 524-526.

Brown, K.M. -1990. The nature and hydrogeologic significance of mud diapirs and diatrems for accretionary systems, J. Geophys. Res., 95(B5): 8969-8982.
Bryden, H.L. - 1993. Sill exchange to and from enclosed seas. In: N.F.R. della Croce (ed.), Symposium Mediterranean Seas 2000, pp. 17-36. University of Genova, Ist. Sc. Amb. Mar., S. Margherita Ligure.

Camerlenghi, A., M.B. Cita, W. Heike and T. Ricchiuto. - 1992. Geological evidence of mud diapirism on the Mediterranean Ridge accretionary complex. Earth Planet. Sci. Lett, 109: 493504 .

Cita, M.B. and C. Corselli. - 1993. Episodic stagnation and anoxic basins in the Eastern Mediterranean. An overview. In: N.F.R. della Croce (ed.), Symposium Mediterranean Seas 2000, pp. 75-99. University of Genova, Ist. Sc. Amb. Mar., S. Margherita Ligure.

Cita, M.B., J.M. Woodside, M. Ivanov, R.B. Kidd, A.F. Limonov and Scientific staff of cruise TTR3-Leg2. - 1994. Fluid venting, mud volcanoes and mud diapirs in the Mediterranean Ridge. Rend. Fis. Acc. Lincei, Ser. 9(5): 159-169.

Cochran, J.K., T. McKibbin-Vaughan, M.M. Dornblaser, D. Hirschberg, H.D. Livingston and K.O. Buesseler. $-1990 .{ }^{210} \mathrm{~Pb}$ scavenging in the North Atlantic and North Pacific Oceans. Earth Planet. Sci. Lett., 97: 332-353.

Corselli, C. and D. Basso. - 1996. First evidence of benthic communities based on chemosynthesis on the Napoli mud volcano (Eastern Mediterranean). Mar. Geol., 132: 227-239.

Corselli, C., D. Basso, G. de Lange, J. Thomson and R/V Urania Leg 18/1994 shipboard party. - 1996. Mediterranean Ridge Accretionary complex yelds rich surprises. EOS Trans., AGU, 77: 227.

D'Alessandro, A., A.A. Ekdale and M. Sonnino. - 1986. Sedimentologic significance of turbidite ichnofacies in the Saraceno formation (Eocene), Southern Italy. J. Sed. Petr., 56(2): 294-306.

Danovaro, R., N. Della Croce, A. Eleftheriou, M. Fabiano, N. Papadopoulou, C. Smith and A. Tselepides. - 1995. Meiofauna of the deep Eastern Mediterranean Sea: distribution and abundance in relation to bacterial biomass, organic matter composition and other environmental factors. Prog. Oceanogr., 36: 329-341.

Danovaro, R., A. Dinet, G. Duineveld and A. Tselepides. - 1999. Benthic response to particulate fluxes in different trophic environments: a comparison between the Gulf of Lions-Catalan Sea Western Mediterranean) and the Cretan Sea (Eastern Mediterranean). Prog. Oceanogr., 44(1-3): 287-312.

DeMaster, D.J. and J.K. Cochran. - 1982. Particle mixing rates in deep-sea sediments determined from excess ${ }^{210} \mathrm{~Pb}_{\text {excess }}$ and ${ }^{32} \mathrm{Si}$ profiles. Earth Planet. Sci. Lett., 61: 257-271.

De Rijk, S., F.J. Jorissen, E.J. Rohling and S.R. Troelstra. - 2000. Organic flux control on bathymetric zonation of Mediterranean benthic foraminifera. Mar. Micropaleontol., 40: 151-166.

Di Geronimo, I. - 1974. Molluschi bentonici in sedimenti recenti batiali e abissali dello Jonio. Conchiglie, 7-8: 133-172.

Ekdale, A.A. - 1985. Paleoecology of the marine endobenthos. Palaeogeogr. Palaeoclimatol. Palaeoecol., 50: 63-81.

Emeis, K.C. and the Shipboard Scientific Party. - 1996. Paleoceanography and sapropel. Introduction. In: K.C. Emeis et al. (eds.), Proceedings of the Ocean Drilling Program, Initial Reports, 160: 21-26.

Emeis, K.C. and T. Sakamoto. - 1998. The sapropel theme of Leg 160. In: A.H.F. Robertson, K.C. Emeis, C. Richter and A. Camerlenghi (eds.), Proceedings of the Ocean Drilling Program, Scientific Results, 160: 29-36.

Fiege, D., I. Kroncke and R. Barnich. - 2000. High abundance of Myriochele fragilis Nilsen and Holthe, 1985 (Polychaeta: Oweniidae) in the deep sea of the Eastern Mediterranean. Hydrobiologia, 426(1-3): 97-103.

Flynn, W.W. - 1968. The determination of low levels of polonium210 in environmental materials. Analytica Chimica Acta, 43: 221-227.

Fredj, G., D. Bellan-Santini and M. Menardi. - 1992. Etat des connaissances sur la faune marine Méditerranéenne, Bull. Inst. Océanogr., 9: 133-145.

Fredj, G. and L. Laubier. - 1983. The deep Mediterranean benthos. In: M. Moraitou-Apostolopoulou and V. Kiortsis (eds.), Mediterranean marine ecosystems, pp. 109-145. NATO Conf. Ser., Plenum Press, New York.

Hausmann K., N. Hulsmann, I. Polianski, S. Schade and M. Weitere. - 2002. Composition of benthic protozoan communities along a depth transect in the Eastern Mediterranean Sea. 
Deep-Sea Res., 49(11): 1959-1970.

Hilgen, F.J. - 1991. Astronomical calibration of Gauss to Matuyama sapropels in the Mediterranean and implication for the geomagnetic polarity time scale. Earth Planet. Sci. Lett., 104: 226-244.

Kidd, R.B., M.B. Cita and W.B.F. Ryan. - 1978. Stratigraphy of eastern Mediterranean sapropel sequences recovered during DSDP Leg42A and their paleoenvironmental significance. Initial Reports of the Deep Sea Drilling Project, 42A: 421-443.

Koutsoubas, D., A. Tselepides and A. Eleftheriou. - 2000. Deep sea molluscan fauna of the Cretan Sea (Eastern Mediterranean): faunal, ecological and zoogeographical remarks. Senckenberg. Marit., 30(3-6): 85-98.

Laubier, L. and C.C. Emig. - 1993. La faune benthique profonde de Méditerranée. In: N.F.R. della Croce (ed.), Symposium Mediterranean Seas 2000, pp. 397-424. University of Genova, Ist. Sc. Amb. Mar., S. Margherita Ligure.

Legeleux, F., J.L. Reyss and S. Schmidt. - 1994. Particle mixing rates in sediments of the northeast tropical Atlantic: evidence from ${ }^{210} \mathrm{~Pb}_{\text {excess, }}{ }^{137} \mathrm{Cs},{ }^{228} \mathrm{Th}_{\text {excess }}$ and ${ }^{234} \mathrm{Th}_{\text {excess }}$ downcore distributions. Earth Planet. Sci. Lett., 128: 545-562.

Legeleux, F., J.L. Reyss, H. Etcheber and A. Khripounoff. - 1996. Fluxes and balance of ${ }^{210} \mathrm{~Pb}$ in the tropical northeast Atlantic. Deep-Sea Res., 43: 1321-1341.

Martínez-Ruíz, F., M. Kastner, A. Paytan, M. Ortega-Huertas and S.M. Bernasconi. - 2000. Geochemical evidence for enhanced productivity during $\mathrm{S} 1$ sapropel deposition in the eastern Mediterranean. Paleoceanogr., 15(2): 200-209.

Moore, W.S. and J. Dymond. - 1988. Correlation of ${ }^{210} \mathrm{~Pb}$ removal with organic carbon fluxes in the Pacific Ocean. Nature, 331: 339-341.

Pemberton, S.G. and R.W. Frey. - 1982. Trace fossils nomenclature and the Planolites-Palaeophycus dilemma. J. Paleontol., 56(4): 843-881.

Psarra, S., A. Tselepides and L. Ignatiades. - 2000. Primary productivity in the oligotrophic Cretan Sea (NE Mediterranean): seasonal and interannual variability. Prog. Oceanogr., 46(2-4): 187-204.

Radakovitch, O., R.D. Cherry and S. Heussner. - 1999. ${ }^{210} \mathrm{~Pb}$ and ${ }^{210} \mathrm{Po}$ : tracers of particle transfer on the Rhône continental margin. Deep-Sea Res., 46: 1539-1563.

Roether, W. and R. Well. - 2001. Oxygen consumption in the Eastern Mediterranean. Deep-Sea Res., 48(6): 1535-1551.

Rossignol-Strick, M. - 1983. African monsoons, an immediate climate response to orbital insolation. Nature, 304: 46-49.

Salas, C. and J. Woodside. - 2002. Lucinoma kazani n.sp. (Mollusca: Bivalvia): evidence of a living benthic community associated with a cold seep in the Eastern Mediterranean Sea. Deep-Sea Res., 49: 991-1005.

Sánchez-Cabeza, J.-A., P. Masqué, M. Martínez-Alonso, J. Mir and I. Esteve. $-1999 .{ }^{210} \mathrm{~Pb}$ Atmospheric Flux and Growth Rates of a Microbial Mat from the Northwestern Mediterranean Sea (Ebro River Delta). Environ. Sci. Technol., 33: 3711 -3715.

Savrda, C.E. and D.J. Bottjer. - 1986. Trace-fossil model for reconstruction of paleo-oxygenation in bottom waters. Geology, 14: 3-6.

Schilman, B., A. Almogi-Labin, M. Bar-Matthews, L. Labeyrie, M. Paterne and B. Luz. - 2001. Long and short-term carbon fluctuations in the Eastern Mediterranean during the late Holocene. Geology, 29(12): 1099-1102.

Schmidt, S. and J.L. Reyss. -1996. Radium as internal tracer of Mediterranean outflow water. J. Geophys. Res., 101: 35893595.

Sibuet, M. and K. Olu. - 1998. Biogeography, biodiversity and fluid dependence of deep-sea cold-seep communities at active and passive margins. Deep-Sea Res., 45: 517-567.

Smith, J.N., B.P. Boudreau and V. Noshkin. - 1987. Plutonium and ${ }^{210} \mathrm{~Pb}$ distributions in northeast Atlantic sediments: subsurface anomalies caused by non-local mixing. Earth Planet. Sci. Lett., 81: $15-28$.

Smith, C.R., L.A. Levin, D.J. Hoover, G. McMurtry and J.D. Gage -2000 . Variations in bioturbation across the oxygen minimum zone in the northwest Arabian Sea. Deep-Sea Res., 47(1-2): 227-257.

Smith, C.R., R.H. Pope, D.J. DeMaster and L. Magaard. - 1993 Age-dependent mixing of deep-sea sediments. Geochim. Cosmochim. Acta, 57: 1473-1488.

Smith, C.R. and C. Rabouille. - 2002. What controls the mixedlayer depth in deep-sea sediments? The importance of POC flux. Limnol. Oceanogr., 47(2): 418-426.

Soetaert, K., P.M.J. Herman, J.J. Middelburg, C. Heip, H.S. deStigter, T.C.E. van Weering, E. Epping and W. Helder. 1996. Modelling ${ }^{210} \mathrm{~Pb}$-derived mixing activity in ocean margin sediments: Diffusive versus nonlocal mixing. J. Mar. Res., 54: 1207-1227.

Sorbe, J.C. and B.S. Galil. - 2002. The bathyal amphipoda off the Levantine coast, eastern Mediterranean. Crustaceana, 75: 957 968.

Souvermezoglou, E. and E. Krasakopoulou. - 1998. Evolution of oxygen and nutrients deep circulation through the straits of the Cretan Arc: impact on the deep layers of the Eastern Mediterranean Sea. Comm. Int. Explor. Sci. Mer Médit., Comité d'Océanographie Physique, 35: 196-197.

Taviani, M. and P. Colantoni. -1984. Deep-sea scleractinian paleobiocenoses from the Malta-Siracusa Escarpment (Mediterranean Sea) - their structure, age and significance. Rev. I. Fr., Petrol. 39: 547-559.

Thomson, J., L. Brown, S. Nixon, G.T. Cook and A.B. MacKenzie - 2000. Bioturbation and Holocene sediment accumulation fluxes in the north-east Atlantic Ocean (Benthic Boundary Layer Experiment sites). Mar. Geol., 169: 21-39.

Thomson, J., S. Colley, R. Anderson, G.T. Cook and A.B. MacKenzie. $-1993 .{ }^{210} \mathrm{~Pb}$ in the sediments and water column of the Northeast Atlantic from 47 to $59^{\circ} \mathrm{N}$ along $20^{\circ} \mathrm{W}$. Earth Planet Sci. Lett., 115: 75-87.

Trauth, M.H., M. Sarnthein and M. Arnold. - 1997. Bioturbational mixing depth and carbon flux at the sea floor. Paleoceanogr., 12: $517-526$

Tselepides, A. and A. Eleftheriou. - 1992. South Aegean (Eastern Mediterranean) continental slope benthos: Macroinfaunal-environmental relationships. In: G.T. Rowe and V. Pariente (eds.), Deep sea food chains and the global carbon cycle, pp. 139-156. Kluwer Academic Publishers, Dordrecht (Netherlands), NATO ASI ser. C: Math. Phys. Sci., Vol. 360.

Turekian, K.K., Y. Nozaki and L.K. Benninger. - 1977. Geochemistry of atmospheric radon and radon products. Earth Planet Sci. Ann. Rev., 5: 227-255.

van Santvoort, P.J.M., G.J. de Lange, J. Thomson, H. Cussen, T.R.S. Wilson, M.D. Krom and K. Strohle. -1996 . Active postdepositional oxidation of the most recent sapropel (S1) in sediments of the eastern Mediterranean Sea. Geochim. Cosmochim. Acta 60: 4007-4024.

Weldeab, S., K.C. Emeis, C. Hemleben, G. Schmiedl and H. Schulz. - 2003. Spatial productivity variations during formation of sapropels S5 and S6 in the Mediterranean Sea: evidence from Ba contents. Palaeogeogr. Palaeoclimatol. Palaeoecol., 191(2): 169-190

Zibrowius, H.-1981. Thanatocoenose pleistocène profonde à Spongiaires et Scléractiniaires dans la Fosse Hellénique. In: J. Rampal (ed.), Journées d'Etudes sur la systématique évolutive et la biogéographie en Méditerranée, pp. 133-136. Comm. Int. Explor. Sci. Mer Médit.

Zibrowius, H. - 1987. Scléractiniaires et Polychètes Serpulidae des faunes bathyales actuelle et plio-pléistocène de Méditerranée. Doc. Trav. IGAL, 11: 255-257. 